\title{
FATE OF IMPORTANT MEDICINAL PLANTS IN THE EASTERN HIMALAYA IN CHANGING CLIMATE SCENARIOS: A CASE OF PANAX PSEUDOGINSENG WALL.
}

\author{
KUMAR, D. ${ }^{{ }^{*}}-$ SINGH, M. ${ }^{2}-$ SHARMA, S. ${ }^{2}$ \\ ${ }^{1}$ G. B. Pant National Institute of Himalayan Environment \& Sustainable Development, Sikkim \\ Regional Centre, Pangthang, Gangtok 737101, Sikkim, India \\ (phone: +91-359-223-7328) \\ ${ }^{2}$ G. B. Pant National Institute of Himalayan Environment \& Sustainable Development, Head \\ Quarters, Kosi-Katarmal, Almora 263643, Uttarakhand, India \\ *Corresponding author \\ e-mail: devendrawii@gmail.com; phone: +91-800-137-3435 \\ (Received 28 $8^{\text {th }}$ Aug 2017; accepted $25^{\text {th }}$ Oct 2019)
}

\begin{abstract}
Monitoring the impact of climate change on forest ecosystems, particularly at the species level, can be currently observed in many parts of the world. In this study, Maxent species distribution modelling algorithm was used to predict the suitable habitat for the medicinally important species; Panax pseudoginseng in Sikkim Himalaya. The nineteen bioclimatic variables from Worldclim database were used to predict the current potential distribution. Representative Concentration Pathway (RCP) 4.5 and RCP 8.5 scenarios of IPCC $5^{\text {th }}$ assessment was used for predicting the future distribution of species in 2050 and 2070. The Maxent model performed better than random with an average test AUC (Area under Curve) value 0.927 under the predicted current distribution. The projected distribution in future under the both RCPs scenarios showed upward shift of species (i.e., gain in suitable habitat area) in high elevation area over the years of 2050 and 2070. Areas with suitable climatic conditions predicted to decline by the 2050s and the 2070s under both RCP scenarios. The application of predictive Maxent modelling approach presented here may provide policymakers and conservationists, with a useful tool for prediction of species in future climate with only presence distribution records and therefore, can be an effective approach for species restoration and conservation actions.
\end{abstract}

Keywords: Himalaya, climate change, conservation, Panax pseudoginseng, medicinal plants

\section{Introduction}

Various components of a landscape (physical, biological and socio economic) are being affected by climate change, mostly along regional temperature changes where impacts due to changes in snow, ice and permafrost regions have influenced ground instability, enhanced glacial melt, enlargement and increase of glacial lakes in mountain regions, hence early and increased spring peak discharges in rivers (IPCC, 2014). Responses of species to impacts of climate change have been manifested in changes in phenology (Corlett et al., 1998; Settele et al., 2016), earlier onset of spring (Mohandass et al., 2015), migration process (Saltré et al., 2015), and lengthening of growing season (IPCC, 2014; Singh and Kushwaha, 2016). Changes in the abundance and distribution range of some species, changes in community composition, and local extinctions of species have been attributed to climate change (Davis and Shaw, 2001; Thomas et al., 2004; Moritz and Agudo, 2013; Maclean et al., 2015). The response of climate change on species distribution could be more rapid and expected to be faster in higher altitude areas, where species occur close to their physiological tolerance (Innes, 1991; Diaz and Bradely, 1997; Gratani, 2014). At regional scale these changes affects the natural 
distribution of species, causing temporal reproductive isolation or even towards the extinction (Araujo et al., 2005; Schröter et al., 2005; Priti et al., 2016; Yi et al., 2016). To reduce the species extinction rates and conservation of its natural habitats in human dominated landscape, delineating protected areas are often the strategy by which conservation can be ensured. Species distribution models (SDMs) is useful in taking important decisions in developing conservation strategies particularly for poorly known or other species (Guisan and Thiller, 2005; Guisan et al., 2013; Cuyckens et al., 2016; de Siqueira et al., 2009; Kumar, 2012; Perez-Garcia et al., 2013; Khanum et al., 2013; Shrestha and Bawa, 2014; Sohel et al., 2016) by providing a strong predictive framework for identifying additional natural populations of species (Menon et al., 2010), and relocating the threatened population of species to natural suitable habitats (Adhikari et al., 2012).

The Himalayan region is experiencing warming at higher rate than the global average (three times high, $0.06{ }^{\circ} \mathrm{C} /$ year; Shrestha et al., 2012). Being a biodiversity hotspot region, Himalaya, and sensitivity towards climate change, information in this region is not adequate and limited to few studies on the aspects of response of species towards climate change (Saran et al., 2010; Kumar, 2012; Forrest et al., 2012; Telwala et al., 2013; Shrestha and Bawa, 2014; Manish et al., 2016). Therefore, this globally important region warrants more understanding on species response towards the climate changes and ecosystem functioning also due to its distinctive evolutionary history and rich species diversity (Pandit and Babu, 1998; Pandit et al., 2007).

Eastern Himalayan region has unique assemblage of endemic plant species and many of them are known for their medicinal values, and among them is Panax pseudoginseng Wall., also known as Himalayan Ginseing is a well known high value medicinal plant. The species is also one of the threatened plant species describes in Red Data Book of India (Nayar and Sastry, 1990). State of Sikkim in the Eastern part of Indian Himalayan region has $31 \%$ of the total geographical area under legal protection of protected area network through one National Park and seven Wildlife Sanctuaries which is much higher than the average of country ( $4 \%$ of total geographical area). Whether the current situation of protected area network in Sikkim Himalaya would encompass the distribution of $P$. pseudoginseng, and what level of research and conservation strategies are required for protection and conservation to manage the natural habitats of $P$. pseudoginseng are key questions on the face of rapid climate changing scenario. In this rationale objectives of this study are: (1) to determine the important climatic variables that enhance prediction for $P$. pseudoginseng in current climatic situations, (2) to model the present predictive distribution range of $P$. pseudoginseng and potential future distribution under two climate change emission scenarios i.e., Representative Concentration Pathways (RCP 4.5 and RCP 8.5) for 2050 and 2070 year, and (3) to propose conservation strategies and management options under different scenarios.

\section{Materials and methods}

\section{Study area}

Sikkim State in Indian Himalayan Region (IHR) is located between $27^{\circ} 00^{\prime} 46^{\prime \prime}$ to $28^{\circ} 07^{\prime} 48^{\prime \prime} \mathrm{N}$ latitudes and $88^{\circ} 00^{\prime} 58^{\prime \prime}$ to $88^{\circ} 55^{\prime} 25^{\prime \prime}$ E longitudes (Fig. 1). The State encompasses four districts (i.e., North Sikkim, East Sikkim, South Sikkim and West Sikkim) covering 7,096 $\mathrm{km}^{2}$ geographical area. This mountainous state has - natural gradient of altitude ranging from $300 \mathrm{~m}$ to $8,586 \mathrm{~m}$ amsl. Biogeographically, Sikkim is 
part of Eastern Himalayan region and has been categorized in two biogeographic zones (Trans Himalaya and Himalaya) of India (Rodgers et al., 2002) - Trans-Himalaya Sikkim (1C) and Eastern Himalaya (2D). Broad representative vegetation types (Champion and Seth, 1968) of the Eastern Himalayan region of India are tropical moist deciduous, subtropical broad leaved forests, Broad leafed and conifer mixed forests, wet temperate forests, sub alpine forests, and alpine meadows (moist and dry alpine scrubs). Protected Area Network in the Sikkim includes seven Wildlife Sanctuaries (Shingba Rhododendron Sanctuary, Kyongnosla Alpine Sanctuary, Pangolakha Wildlife Sanctuary, Fambonglho Wildlife Sanctuary, Maenam Wildlife Sanctuary, Barsey Rhododendron Sanctuary and Kitam Bird Sanctuary), and one National Park (Khangchendzonga NP), covering a total area of $2183.1 \mathrm{~km}^{2}$, which is $30.8 \%$ of the total geographical area of the State.
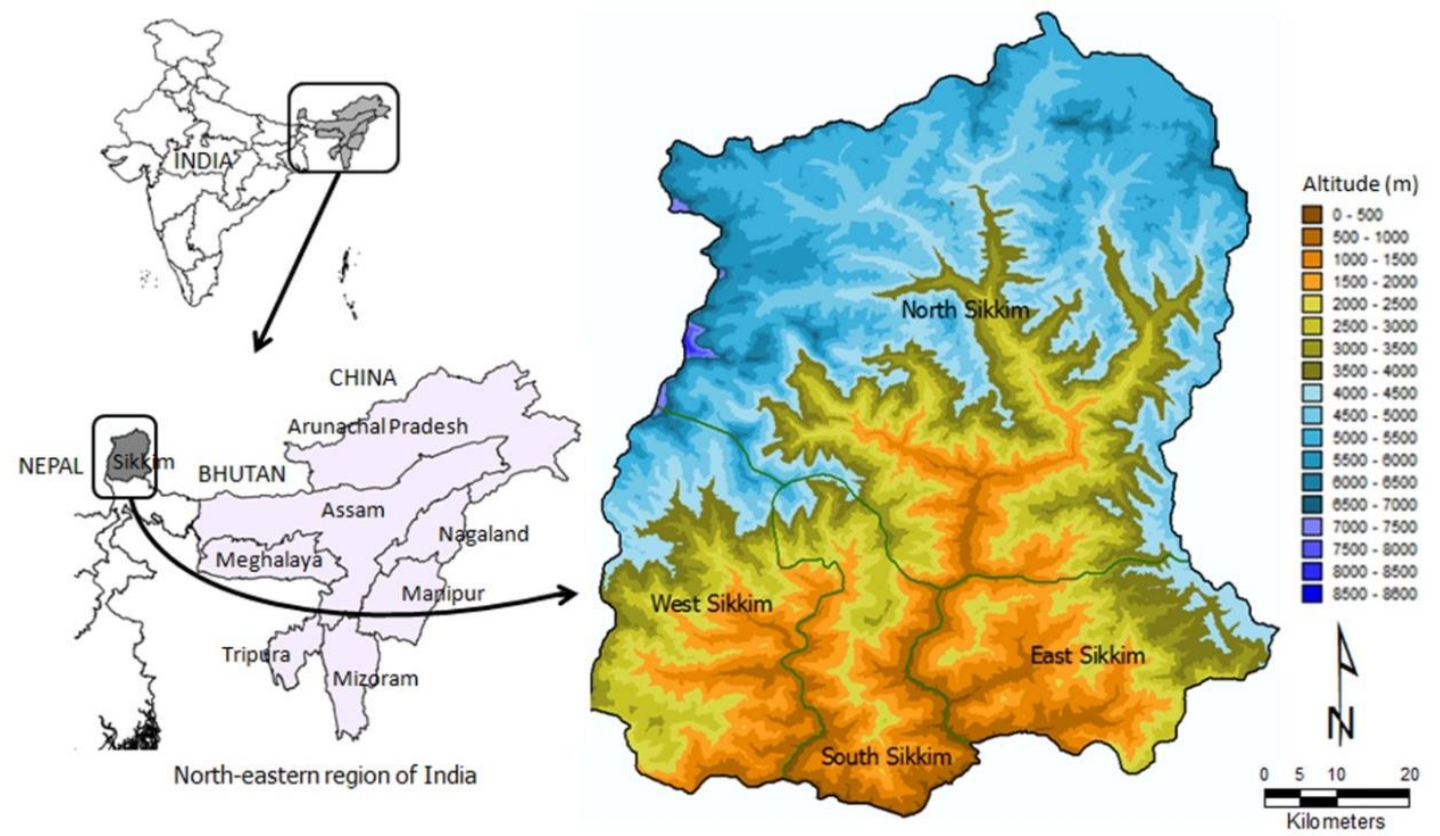

Figure 1. Map of study area showing the districts and elevation gradients of Sikkim Himalaya

\section{Study species}

Panax pseudoginseng Wall. (Araliaceae) [syn. Aralia pseudoginseng (Wall.) Benth. ex C.B. Clarke; Aralia quinquefolia Decne. \& Planch. var. pseudoginseng (Wall.) Burkill; Panax schinseng var. nepalensis Nees; Panax sikkimensis R.N. Banerjee] is commonly known as Himalayan Ginseng, Indian Ginseng and False Ginseng. It is a perennial herb that grows up to $50 \mathrm{~cm}$ in height (Clarke, 1879). It is distributed in temperate zone of thick conifer-oak mixed and Himalayan birch forests where the soils has deep humus content. The species starts flowering during the months of May-June and fruiting during July-October. The flowers are terminal, unequal, umbellate and pale green or orange-yellow in colour. Its bear's dull green to black fruits measuring 3-5 mm with a black spot at the top part. Medicinally the Himalayan Ginseng is well-liked to known as elixir of life and its rhizomes uses for preparation of rejuvenating and revitalizing tonic. It is used to increase longevity, mental agility and to check hypertension. Locally it is used as a haemostatic for treating conditions such as 
vomiting and coughing up of blood, blood in the urine or stool, bleeding nose and hemorrhagic disease.

Known habitats of $P$. pseudoginseng in this study are under sub-alpine zone between 3000 and $4000 \mathrm{~m}$ amsl, which comprises locations those remain moist for 8-9 months, and dry season for 3-4 months. A cold climate is normal for all the locations and dew, frosts or days under snow occur as regular events at some locations. The plant normally grows under shade and most abundantly under canopy of Abies densa, Betula spp., Lithocarpus pachyphyllus and Rhododendron spp., however, occasionally it can be found in open forests also.

\section{Species presence data}

Herbarium records of the species were analyzed from the collection of Botanical Survey of India, Sikkim Office. All the herbarium sheets (12 in number) were georeferenced through location of collections on the maps, this was followed by field surveys and ten new locations were also recorded, thus leading to a total of 22 locations for current presence data. These locations were transferred to GIS platform using Arc GIS software.

\section{Environmental predictors}

Nineteen bioclimatic variables are available from WorldClim database (http://www.worldclim.org) at a resolution of approximately $1 \mathrm{~km}$ (Hijmans et al., 2005) was used for distribution modeling of $P$. pseudoginseng. These variables, derived principally from monthly temperature and precipitation data (Table 1), have proven relevance in modeling species distribution (Pearson and Dawson, 2003; Irfan-Ullah et al., 2007; Loiselle et al., 2008; Khanum et al., 2013). Intergovernmental Panel on Climate Change (IPCC) 5 data for future climate projection conditions for the years 2050s and 2070s were obtained from the Consultative Group on International Agricultural Research (CGIAR)'s Research Program on Climate Change, Agriculture and Food Security (CCAFS) climate data archive (http://www.ccafs-climate.org/) to project the potential distribution in future.

The future climatic projection datasets are based on of IPCC $5^{\text {th }}$ assessment and were calibrated and downscaled using the current climatic data. Instead of using single global circulation model (GCM), we used data from three different global climate models for reducing the uncertainty. MRI-CGCM3, CSIRO-MK3.6 and HadGEM2-CC global climate models were selected for modeling the future prediction (Khanum et al., 2013; Barber, 2015; Dotchamou et al., 2016). Each GCM was tested under two future greenhouse gas concentration trajectories, called Representative Concentration Pathways (RCP) i.e., RCP 4.5 and RCP 8.5 for the periods 2050 and 2070. The RCP 4.5 ("intermediate stabilization pathways") was developed by Pacific Northwest National Laboratory's in the United States. It is relatively stable scenario in which total radiative forcing reaches $4.5 \mathrm{~W} / \mathrm{m}^{2}$ and stabilized shortly after 2100 , without overshooting the long-run radiative forcing target level (Clarke et al., 2007; Smith and Wigley, 2006; Wise et al., 2009). The RCP 8.5 was developed by the International Institute for Applied System Analysis in Austria. It is characterized by increasing greenhouse gas emissions throughout the $21^{\text {st }}$ century and radioactive forcing is predicted to reach up to $8.5 \mathrm{~W} / \mathrm{m}^{2}$ by 2100 (Riahi et al., 2007; Riahi et al., 2011). These two scenarios are being used by various workers to analyze impacts of climate change on predictive species 
distribution modeling (Monahan et al., 2013; Shrestha and Bawa, 2014; Li et al., 2015; Kang et al., 2016; Sohel et al., 2016; York et al., 2016). For future potential distribution predictions of $P$. pseudoginseng, we ran separate models (Appendix) and also by averaging the results (ensemble approach) from the CGCM3, CSIRO-MK3 and HadGEM2-CC future climate models (Araujo and New, 2007).

Table 1. Percentage contribution (average of over twenty replicate runs) and permutation importance of the climatic variables in the Maxent models for Panax pseudoginseng

\begin{tabular}{|c|c|c|c|c|}
\hline Climatic variable & Code & Unit & $\begin{array}{c}\text { Percentage } \\
\text { contribution }\end{array}$ & $\begin{array}{l}\text { Permutation } \\
\text { importance }\end{array}$ \\
\hline Annual mean temperature [AMT] & Bio1 & ${ }^{\circ} \mathrm{C}$ & - & - \\
\hline Mean diurnal range temperature $\{$ Mean of monthly (max temp - min temp) $\}[$ MDRT] & Bio2 & ${ }^{\circ} \mathrm{C}$ & - & - \\
\hline Isothermality (Bio2/Bio7) $(* 100)[$ ISO] & Bio3 & & 0.1 & 0.3 \\
\hline Temperature seasonality (Standard deviation *100) [TS] & Bio4 & & - & - \\
\hline Maximum temperature of warmest month [MTWM] & Bio5 & ${ }^{\circ} \mathrm{C}$ & - & - \\
\hline Minimum temperature of coldest month [MTCM] & Bio6 & ${ }^{\circ} \mathrm{C}$ & - & - \\
\hline Temperature annual range (Bio5-Bio6) [TAR] & Bio7 & ${ }^{\circ} \mathrm{C}$ & 0.8 & 0.0 \\
\hline Mean temperature of wettest quarter [MTWQ] & Bio8 & ${ }^{\circ} \mathrm{C}$ & - & - \\
\hline Mean temperature of driest quarter [MTDQ] & Bio9 & ${ }^{\circ} \mathrm{C}$ & - & - \\
\hline Mean temperature of warmest quarter [MTWAQ] & Bio10 & ${ }^{\circ} \mathrm{C}$ & 8.5 & 21.9 \\
\hline Mean temperature of coldest quarter [MTCQ] & Bio11 & ${ }^{\circ} \mathrm{C}$ & 25.6 & 76.6 \\
\hline Annual precipitation [AP] & Bio12 & $\mathrm{mm}$ & - & - \\
\hline Precipitation of wettest month [PWM] & Bio13 & $\mathrm{mm}$ & - & - \\
\hline Precipitation of driest month [PDM] & Bio14 & $\mathrm{mm}$ & - & - \\
\hline Precipitation seasonality (Coefficient of variation) [PS] & Bio15 & & 60.2 & 0.7 \\
\hline Precipitation of wettest quarter [PWQ] & Bio16 & $\mathrm{mm}$ & - & - \\
\hline Precipitation of driest quarter [PDQ] & Bio17 & $\mathrm{mm}$ & - & - \\
\hline Precipitation of warmest quarter [PWAQ] & Bio18 & $\mathrm{mm}$ & 4.8 & 0.6 \\
\hline Precipitation of coldest quarter [PCQ] & Bio19 & $\mathrm{mm}$ & - & - \\
\hline
\end{tabular}

\section{Predictive Maxent modeling}

For the prediction modelling, maximum entropy based technique i.e., Maxent ver. 3.3.3k (http://www.cs.princeton.edu/ schapire/Maxent/) was chosen due to its better performance with small sample sizes relative to other modelling algorithms (Elith et al., 2006). This programme attempts to estimate a species distribution by finding the probability distribution of species occurrence i.e., closest to uniform subject to the constraint that the mean environmental conditions by the model should be close to the empirical average of the conditions at the presence localities (Phillips et al., 2006; Phillips and Dudik, 2008; Elith et al., 2011).

A total of twenty replicate runs were set for model building and averaged the result. In the replicated runs the cross validation technique was used, where samples divided into replicate folds and each fold was used for test data. Jackknife test and percent variable contributions were used to estimates the relative influence of different predictor variables, which estimate the training gain of every variable and recommend the best interpreter for the prediction of distribution of species. The AUC (area under curve), area under the ROC (Receiver Operating Characteristics) curve, was used to evaluate model performance. However, ROC AUC provides a threshold-independent measure of model performance compared to that of null expectations, such should provides an overall picture of the predictive nature of models (Stockwell and Peterson, 2002; 
Fawcett, 2006). An AUC statistic closer to 0.5, indicates that model did not perform better than random whereas closer to 1.0, indicates perfect discrimination (Swets, 1988). Araujo et al. (2005) recommended the following interpretation of AUC for the models generated, viz., excellent if AUC $>0.90$; Good if $0.80>$ AUC $<0.90$; Acceptable if $0.70>$ AUC $<0.80$; Bad if $0.60>$ AUC $<0.70$; Invalid if $0.50>$ AUC $<0.60$.

The multi-collinearity test was conducted using pairwise Pearson's correlation coefficient (r) to examine the cross-correlation among the climatic variables using the ENM tool (Warren et al., 2010). The variables with cross-correlation coefficient value of $\geq+0.90$ were excluded from the analysis (see Table Al in the Appendix). Based on such criterion, 13 bioclimatic variables were excluded and only 6 bioclimatic variables were used in the final model to predict the effect of climate change on the future distribution of $P$. pseudoginseng. For validating the model robustness a 10 percentile training presence threshold rule was executed over a twenty replicated model runs (Pearson et al., 2004). Other parameters were set to default as the program is already calibrated on a wide range of species datasets as suggested by Phillips and Dudik (2008). To avoid erroneous predictions of suitable habitat under future climate scenarios for 2050 and 2070 'fade by clamping' option was used in Maxent, which removes heavily clamped pixels from the final predictions (Fielding and Bell, 1997; Phillips et al., 2006). For each of the three habitat models, including the current $P$. pseudoginseng potential distribution and the two future predictions under the RCP scenarios (2050 and 2070), we calculated the total area of habitats, and amounts of stable/no change (areas of the current potential range predicted to remain suitable), unsuitable, lost (areas not predicted to remain suitable in future), and gained habitats (areas that are predicted to be suitable future that are not currently suitable) areas for each of the two future models under 2050 and 2070 years.

\section{Results}

The selected climatic variables, 6 in number, provided a satisfactory prediction of the potential current distribution of species ( $P$. pseudoginseng) evident by mean test AUC value of $0.927 \pm 0.043$, and considered excellent (Araujo et al., 2005). Amongst these climatic variables, precipitation seasonality (PS) and mean temperature of coldest quarter (MTCQ) appeared significant for the occurrence of the species (collectively contributed to $85.8 \%$ of the model's variance; Table 1) indicating role of moisture and cold environment as apparent by contribution of Mean temperature of warmest quarter (MTWAQ) and precipitation of warmest quarter (PWAQ). Temperature annual range (TAR) and isothermality (ISO) made the lowest contribution to the predictive model. Considering the permutation importance, MTCQ had the maximum influence on model and contributed to $76.6 \%$, followed by mean temperature of warmest quarter (MTWAQ), i.e., 21.9\% (Table 1). Climatic profiles (based on the occurrence records; minimum, maximum and mean value of nineteen current climatic variables) for the species under investigation are presented in Table 2.

The current suitable habitats for $P$. pseudoginseng, covering $14.4 \%$ of the total geographical area, are confined to mainly in central part of North Sikkim district, northeastern part of East Sikkim district, north-western part of West Sikkim district, with some patches in northern part of South Sikkim district (Fig. 2a). The Jackknife test estimated the training gains of each predictor variable, when a variable is used in separation, when it is excluded, and when all variables are utilized. The graph of 
Jackknife predictor test indicates that the MTCQ and PS as main factors influencing the distribution pattern and has highest training gain (Fig. 3a). The response curve of $P$. pseudoginseng showed that the predicted habitat suitability area was initially increased sharply with increasing PS and was bell shaped with MTCQ (Fig. 3b,c). Areas with suitable climatic conditions for $P$. pseudoginseng are predicted to decline by the 2050 s and the 2070s under both RCP scenarios. Averaged future predictions from three climatic models under an intermediate scenario (RCP 4.5) of 2050 showed loss of suitable area $\left(190.88 \mathrm{~km}^{2} ; 2.69 \%\right)$; while further loosing the suitable habitat area over the year $2070\left(266.1 \mathrm{~km}^{2} ; 3.75 \%\right)$ (Fig. 2b, c; Table 3). The loss of suitable habitat area in average model of RCP 4.5 scenario was predicted mainly in patches form of northern part of West Sikkim and central parts of North Sikkim districts for year 2050, whereas in 2070 the loss predicted continuously over the north-western part of West Sikkim, northern part of South Sikkim, north-eastern part of East Sikkim and, central and northeastern part of North Sikkim districts (Fig. 2b, c). Conversely, in higher scenario (RCP 8.5) the loss of suitable habitat areas was predicted continuously in northern part of West and South Sikkim districts, and in patches form of north-eastern parts of North and East Sikkim districts for year 2050, whereas in 2070 the loss predicted continuously over the entire four districts of Sikkim (Fig. 2d,e). However, the loss of suitable area predicted under a RCP 8.5 was more than RCP 4.5 for $2050\left(307.26 \mathrm{~km}^{2} ; 4.3 \%\right)$, which further continuously lost predicted suitable habitat over the year of $2070\left(63,509 \mathrm{~km}^{2}\right.$; 8.95\%) (Fig. 2d, e; Table 3). Those scenarios also decreased the number of suitable patches (i.e. no change/stable) in RCPs 4.5 by $8.21 \%$ to $7.51 \%$ and RCP 8.5 by $6.57 \%$ to $1.95 \%$, over the years 2050 to 2070 respectively. Another common feature for projected distribution in future climate models under the both RCPs scenarios (4.5 and 8.5), was the upward shift of species (i.e., gain in suitable habitat area) in high elevation area over the years of 2050 and 2070.

Table 2. Climatic profile of Panax pseudogensing based on herbarium and presence records

\begin{tabular}{c|c|c|c|c|c|c}
\hline Climatic variable & Code & Unit & Min. & Max. & Mean & SD \\
\hline Annual mean temperature [AMT] & Bio1 & ${ }^{\circ} \mathrm{C}$ & 3.1 & 8.2 & 4.9 & 1.6 \\
Mean diurnal range temperature \{Mean of monthly (max temp - min temp)\}[MDRT] & Bio2 & ${ }^{\circ} \mathrm{C}$ & 9.6 & 13.0 & 12.1 & 1.0 \\
Isothermality (Bio2/Bio7) (* 100) [ISO] & Bio3 & & 45.0 & 47.0 & 45.8 & 0.6 \\
Temperature seasonality (Standard deviation *100) [TS] & Bio4 & & 4271.0 & 5561.0 & 5167.5 & 380.2 \\
Maximum temperature of warmest month [MTWM] & Bio5 & ${ }^{\circ} \mathrm{C}$ & 14.3 & 18.3 & 15.8 & 1.3 \\
Minimum temperature of coldest month [MTCM] & Bio6 & ${ }^{\circ} \mathrm{C}$ & -13.1 & -4.0 & -10.3 & 2.5 \\
Temperature annual range (Bio5-Bio6) [TAR] & Bio7 & ${ }^{\circ} \mathrm{C}$ & 21.1 & 28.2 & 26.2 & 2.1 \\
Mean temperature of wettest quarter [MTWQ] & Bio8 & ${ }^{\circ} \mathrm{C}$ & 9.4 & 13.3 & 11.0 & 1.3 \\
Mean temperature of driest quarter [MTDQ] & Bio9 & ${ }^{\circ} \mathrm{C}$ & -3.2 & 3.2 & -1.1 & 1.8 \\
Mean temperature of warmest quarter [MTWAQ] & Bio10 & ${ }^{\circ} \mathrm{C}$ & 9.4 & 13.3 & 11.0 & 1.3 \\
Mean temperature of coldest quarter [MTCQ] & Bio11 & ${ }^{\circ} \mathrm{C}$ & -4.2 & 2.2 & -2.1 & 1.9 \\
Annual precipitation [AP] & Bio12 & $\mathrm{mm}$ & 626.0 & 1400.0 & 806.0 & 211.7 \\
Precipitation of wettest month [PWM] & Bio13 & $\mathrm{mm}$ & 126.0 & 319.0 & 168.6 & 51.9 \\
Precipitation of driest month [PDM] & Bio14 & $\mathrm{mm}$ & 3.0 & 9.0 & 5.3 & 1.7 \\
Precipitation seasonality (Coefficient of variation) [PS] & Bio15 & & 73.0 & 90.0 & 81.4 & 5.8 \\
Precipitation of wettest quarter [PWQ] & Bio16 & $\mathrm{mm}$ & 340.0 & 818.0 & 449.8 & 132.0 \\
Precipitation of driest quarter [PDQ] & Bio17 & $\mathrm{mm}$ & 20.0 & 49.0 & 28.1 & 8.7 \\
Precipitation of warmest quarter [PWAQ] & Bio18 & $\mathrm{mm}$ & 340.0 & 818.0 & 449.8 & 132.0 \\
Precipitation of coldest quarter [PCQ] & Bio19 & $\mathrm{mm}$ & 30.0 & 62.0 & 40.1 & 9.7 \\
\hline
\end{tabular}



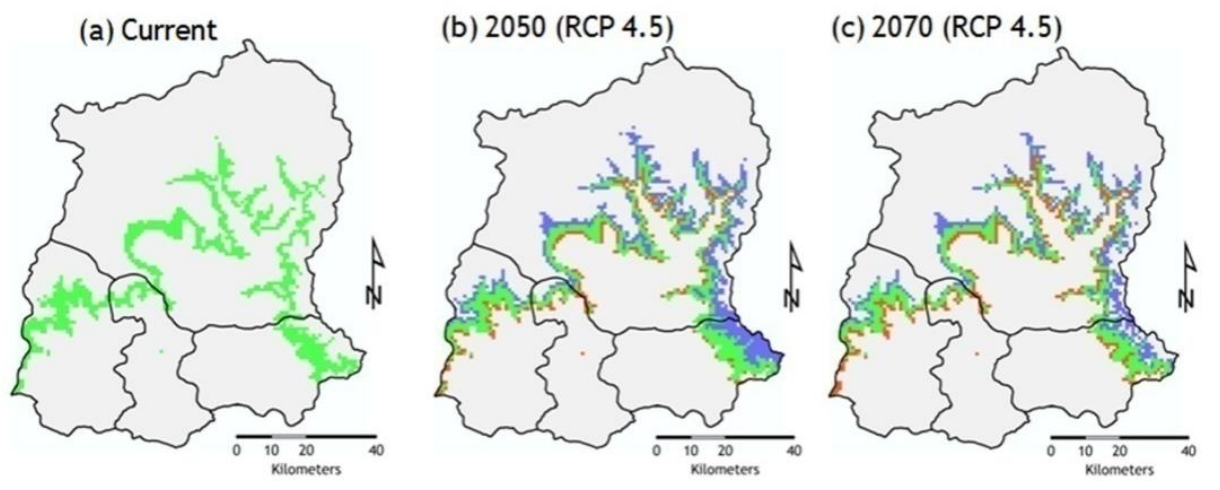

(d) 2050 (RCP 8.5)
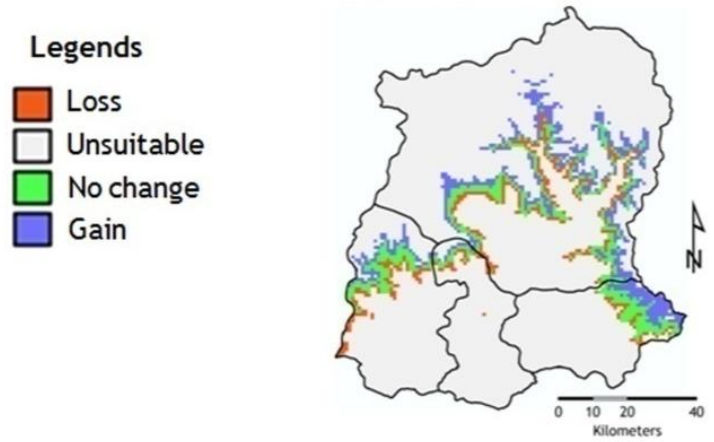

(e) 2070 (RCP 8.5)

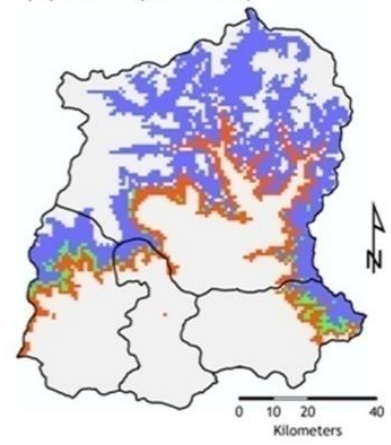

Figure 2. Predicted (a) current and (b-e) future (Suitable/no change, loss, gain and unsuitable) habitats of P. pseudoginseng for the years 2050 and 2070, under RCP 4.5 and RCP 8.5 climate change scenarios
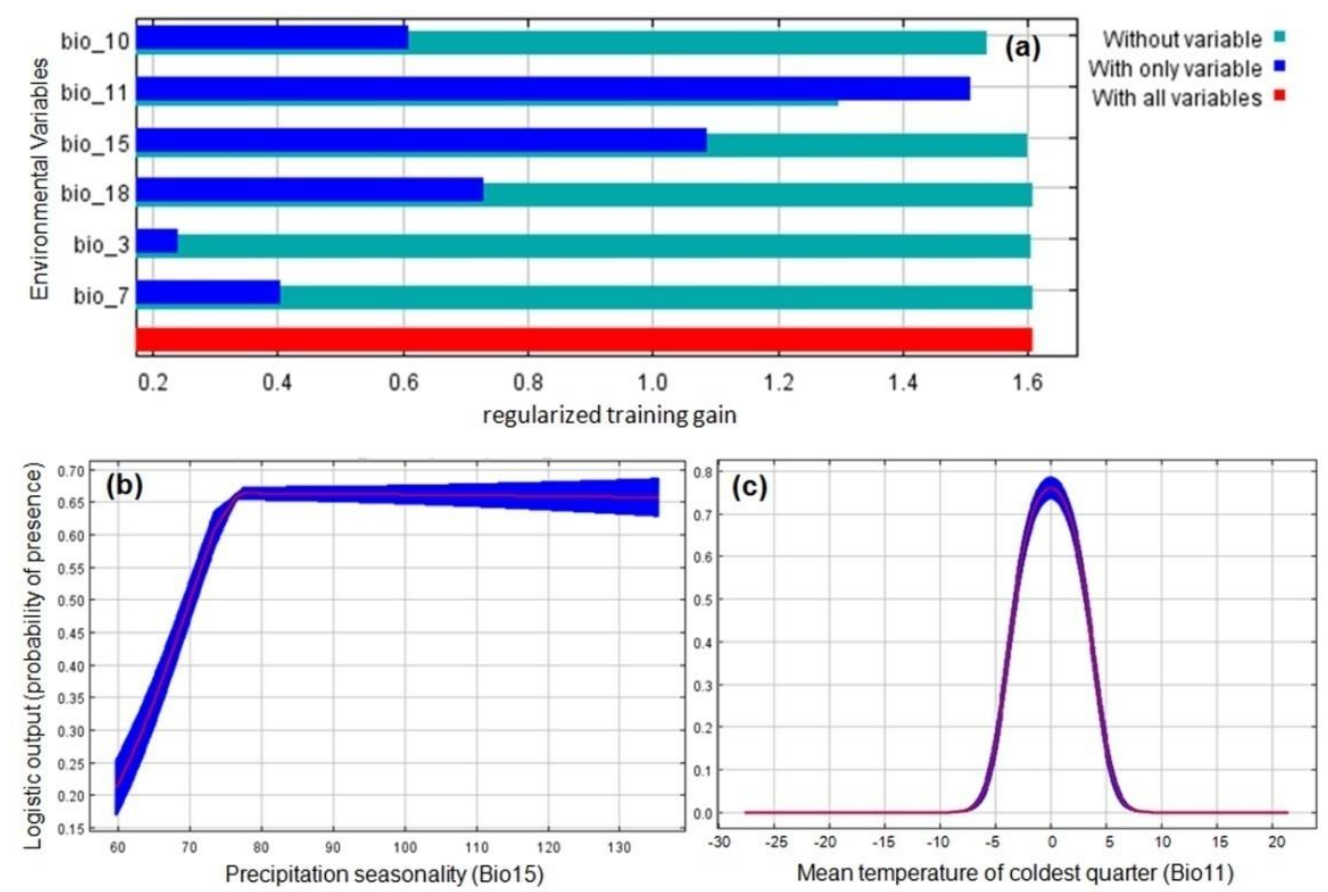

Figure 3. (a) Jackknife regularized training gain, showing the relative predictive power of bioclimatic variable; and $(b)$ response curves showing the relationships between probability of presence of a species and climatic variables. (Values shown are average of twenty replicate run) 
Table 3. Predicted suitable habitat areas for P. pseudogensing under each climate change scenarios

\begin{tabular}{|c|c|c|c|c|c|c|c|c|c|c|}
\hline \multirow{3}{*}{ Classes } & \multicolumn{5}{|c|}{ Area $\left(\mathbf{k m}^{2}\right)$} & \multicolumn{5}{|c|}{ Area $(\%)$} \\
\hline & \multirow{2}{*}{ Current } & \multicolumn{2}{|c|}{ RCP 4.5} & \multicolumn{2}{|c|}{ RCP 8.5} & \multirow{2}{*}{ Current } & \multicolumn{2}{|c|}{ RCP 4.5} & \multicolumn{2}{|c|}{ RCP 8.5} \\
\hline & & 2050 & 2070 & 2050 & 2070 & & 2050 & 2080 & 2050 & 2070 \\
\hline Suitable/No change & 1,025 & 582.58 & 507.36 & 466.21 & 138.37 & 14.44 & 8.21 & 7.15 & 6.57 & 1.95 \\
\hline Loss & & 190.88 & 266.10 & 307.26 & 635.09 & & 2.69 & 3.75 & 4.33 & 8.95 \\
\hline Gain & & 491.04 & 374.67 & 510.91 & 1871.92 & & 6.92 & 5.28 & 7.20 & 26.38 \\
\hline Unsuitable & & $5,831.49$ & $5,947.87$ & $5,811.62$ & $4,450.61$ & & 82.18 & 83.82 & 81.90 & 62.72 \\
\hline
\end{tabular}

\section{Discussion}

The modelling result suggests that the suitable habitat area for Panax pseudoginseng (Himalayan Ginseng) would shrink under the predicted levels of climate change in future. The Maxent model performed better than random, with satisfactory mean test AUC value. Maxent predicted the upward shifts of (i.e., more than $4000 \mathrm{~m}$ high elevated zones) $P$. pseudoginseng suitable area under the both intermediate and high scenarios, with greater risk of habitat loss from current suitable predicted areas in Sikkim Himalaya. Field observation suggest the Himalayan Ginseng is highly dependent on local climates, the plant thrives only when there is moist soil humus content at places ranging between 3000$4000 \mathrm{~m}$ elevations, due to this the species has confined distribution in eastern Himalayan region of India. Maxent model result shows, predicted suitable habitat area under the current climatic condition would become unsuitable in predicted future climate change scenarios, resulting in local extinction of the species.

Considering climate sensitive plants, the seasonality (such as temperature, rainfall, humidity, soil temperature, soil moisture content and day length) expose them to regular periodic changes in the quality and abundance of resources (Franklin et al., 1992). All of these factors are known to play a role, only or in combination with, in triggering the phenological or physiological changes. Some species may be capable of adapting to future climatic condition through phenological changes (such as early or late flowering/fruiting) or through adaptation towards microclimate conditions responsible for survival of its natural population. In this investigation, Himalayan Ginseng showed the range expansions of suitable habitat towards higher elevated zones in future climate change scenarios, which may be to make possible through adaptation towards the changes in local climatic condition. Khanum et al. (2013) showed similar results of adaptation and range expansion of species for predicting the impact of climate change of three important medicinal asclepiads in Pakistan. Midgley et al. (2006) suggested that, in predicting the impact of climate changes on plant species the dispersal of seed is also a regulating factor for adaptation of species. A study across twenty-six mountains in Switzerland demonstrated that, the alpine flora expanded their ranges upward towards the peaks (Grabherr et al., 1994; Pauli et al., 1996) and a similar study by Moiseev and Shiyatov (2003) showed the upward movement of treelines in Siberia.

While generalizing the ecosystem responses towards the rapid warming in the Himalayan region, Singh et al. (2010) have reported that the woody species of higher elevated zones have began to invade the alpine meadows, and result in a complex series of changes in ecosystem functioning process with involvement of the soil subsystems. Another hypothesis is the future exploitations pressure on this plant species will make coping difficult against the climate changes and this could cause the extinction of this species despite good showing in the current and future climate suitable habitats (Svenning et al., 
2009). The present study shows that Himalayan Ginseng is threatened under the predicting climate change scenarios in Sikkim, Himalaya; a similar kind of results have been reported from another studies for economically important species, viz., studies on Baobab trees by Sanchez et al. (2011); on medicinal Asclepiads in Pakistan by Khanum et al. (2013); on Caterpiller fungus in Nepal by Shrestha and Bawa (2014) and on Dysoxylum binectariferum by Sohel et al. (2016) in northeastern part of Bangladesh. Another parameter such as soil and land transformations would also become the contributing factor for predicting the species response in climate change (Pearson and Dawson, 2005), but the present study did not incorporate these parameters, due to unavailability of datasets.

Species with known economic importance value experiences pressures, (i.e., loss of natural habitats from climate change events, changes in landuse and land cover patterns, and overexploitation) because of their known utility (Pandit et al., 2007). These threats adversely affect natural plant resources in Himalayan region of India. The high medicinal important is responsible for their extraction from the wild which has already reduced the population sizes of Himalayan Ginseng in the natural population (Pandit and Babu, 1998). Loss of natural habitats due to deforestation, developmental works and expansion of agricultural practices have driven many of the endemic and medicinally important plant species to the brink of extinction in Himalaya region (Pandit et al., 2007). The Himalayan Ginseng is already listed as threatened taxa in the Red Data Book of India (Nayar and Sastry, 1990). On regional scale the climate change is one of the greatest challenges for conserving the biodiversity and forests ecosystems. Changes have already reported in different region, including impact of change on plant biodiversity in Europe (Thuiller et al., 2005), plant species vulnerability to climate change in Peninsular Thailand (Trisurat et al., 2011), declines of woody plant species ranges under climate change in Yunnan, China (Zhang et al., 2014) and extinction of freshwater swamp forest trees (Pongamia pinnata and Barringtonia acutangula) of Bangladesh in climate change scenarios (Deb et al., 2016).

Conservation of natural plant resources at species level has often failed owing to lack of proper knowledge of the target species in term of habitat suitability. The application of Ecological Niche Models (ENMs) to extract simple inventory data (such as presence records of species) may provide predictions of species under changing climates at both regional and local scale, and the models may be used to make recommendations for policymakers and conservationists in dealing with potential climate change (Sanchez et al., 2011). Here, we used the maximum entropy based modelling techniques, as implemented in the ENM software Maxent (Phillips et al., 2006; Elith et al., 2006, 2011), to summarize the climatic niche of the Himalayan Ginseng to predict changes in climate change emission scenarios. Maxent accounts for some consequences, for example, it does not estimate the probability of occurrence directly, but rather the environmental suitability for the species that can be mapped in a geographic space (Royle et al., 2012). Considerably, it is the most widely used and has good predictive power capabilities (Elith et al., 2006). Maxent have been used extensively for investigating plant and animal responses to climate change (Trisurat et al., 2011; Chitale and Behera, 2012; Khanum et al., 2013; Kumar, 2013; Shrestha and Bawa, 2014; Alamgir et al., 2015; Cuyckens et al., 2016; Sohel et al., 2016).

\section{Conservation strategies}

Considering the results in this study by predictive Maxent modelling on distribution of Himalayan Ginseng in Sikkim Himalaya, there will be moderate to high impacts under the future climate change scenarios. The most of suitable habitat area predicted for this plant 
species might already be devoid of populations due to transformation of landuse, and overexploitations by local people for economic gain. A recent investigation on predicting the impact of climate change on a tree species (Dysoxylum binectariferum) in north-eastern part of Bangladesh by Sohel et al. (2016) suggested that the combined effect of human induced anthropogenic factors and change in climate condition in future will increase the extent of unsuitable habitat for the plant. Therefore, successful management plan for conserving the natural population in human dominated landscape is needed which can be used to address the issues and generate connectivity across protected areas (Urbina-Cardona and Flores-Villela, 2010). Besides designating a new protected area, the existing protected areas should have successful management plan for conservation and restoration of key species. These management plans should consider ecotourism, restriction of grazing, firewood collection and forest fire, involving the field researchers, NGOs and local communities. The subtropical to temperate and alpine areas of Sikkim is of special conservation interest as it is also suitable area for the conservation of key species such as the Snow Leopard (Sathyakumar et al., 2011b; Forrest et al., 2012), Red Panda (Ghose et al., 2011), Rhododendrons (Kumar, 2012) and for Galliformes (Sathyakumar et al., 2011a) in different protected area of Sikkim. This is also the area where Himalayan Ginseng exhibits the highest generic diversity (Sharma and Pandit, 2011).

Another possible conservation strategy for Himalayan Ginseng, especially for areas at high risk of habitat loss, e.g., in Pangolakha Wildlife Sanctuary and Barsey Rhododendron Sanctuary (Fig. 2), could be compensated by ex situ germplasm collection and micropropagation techniques, as suggested by Sanchez et al. (2011) for Baobab trees in Africa. Moreover, results of habitat loss do not necessarily suggest extinction but certainly increase the local extinction risk (Alarcón and Cavieres, 2015). The Convention on Biodiversity (CBD) suggested that a minimum representation of species habitat at ecosystem level should be under protection between 10-12\% (Burgess et al., 2005; Tear et al., 2005), or $17 \%$ for terrestrial ecosystems (Moilanen et al., 2013). In this study, the current network of PAs accomplishes and even surpasses this suggestion area (at 30.8\%) where, most of the natural population of Himalayan Ginseng are growing (Fig. 4). Table 4 showed the area statistics of predicted potential habitats for Himalayan Ginseng in current climatic condition under different PAs network of Sikkim. The most effective strategy for protecting the Himalayan Ginseng viable populations in the areas of suitable future habitat is through conservation or sustainable utilization (Sanchez et al., 2011). For example, if local peoples are made aware that they may reap higher economic benefits from this plant left in their natural habitat than if grown as a crop this change in priority of action would yield better conservation outcome for the Himalayan Ginseng.

Table 4. Present projection of suitable habitat area of P. pseudogensing in different PAs of Sikkim

\begin{tabular}{c|c|c|c}
\hline \multicolumn{2}{c|}{ Protected area } & \multicolumn{2}{c}{$\begin{array}{c}\text { Predicted potential area habitat for P. } \\
\text { pseudogensing }\end{array}$} \\
\hline Name & Area $\left(\mathbf{k m}^{\mathbf{2}}\right)$ & $\mathbf{k m}^{\mathbf{2}}$ & $\mathbf{\%}$ \\
\hline Khangchendzonga National Park & 1784.00 & 290.46 & 16.28 \\
Shingba Rhododendron Sanctuary & 43.00 & 18.77 & 18.71 \\
Kyangnosla Alpine Sanctuary & 31.00 & 36.55 & 28.55 \\
Pangolakha Wildlife Sanctuary & 128.00 & 0.56 & 1.58 \\
Maenam Wildlife Sanctuary & 35.34 & 8.60 & 8.27 \\
Barsey Rhododendron Sanctuary & 104.00 & $\mathbf{3 7 3 . 6 5}$ & $\mathbf{1 7 . 5 8}$ \\
\hline
\end{tabular}



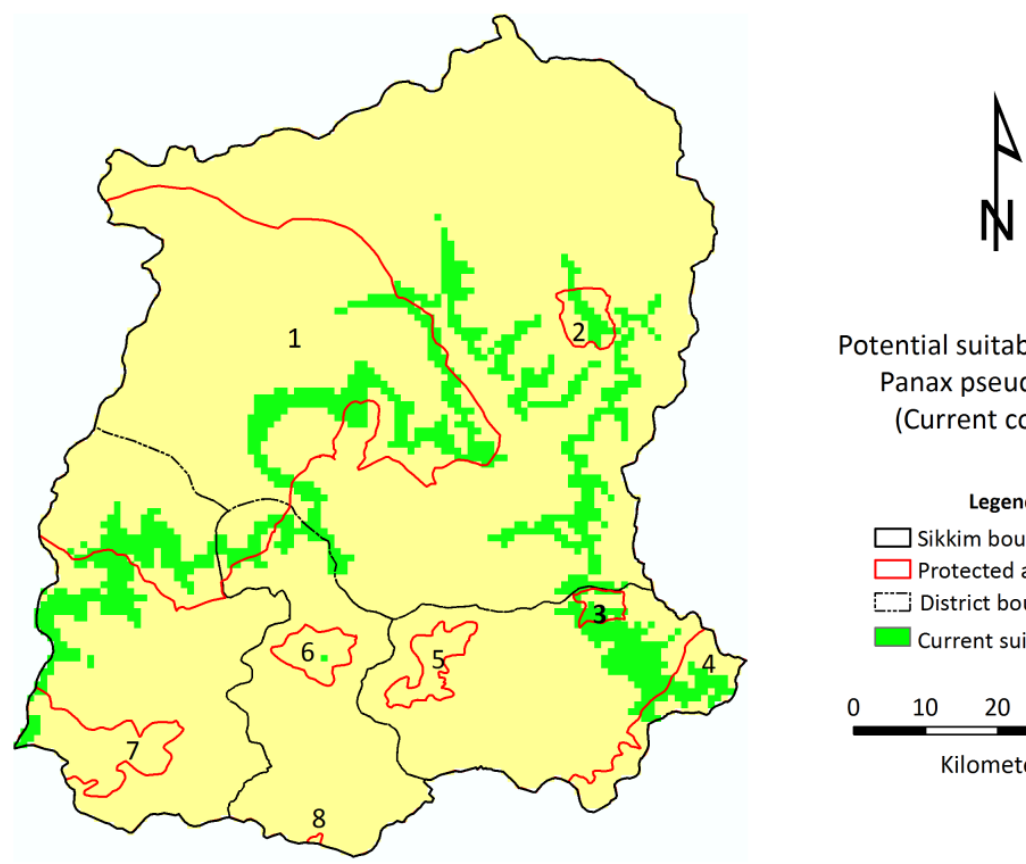

Potential suitable habitat of Panax pseudogensing (Current condition)

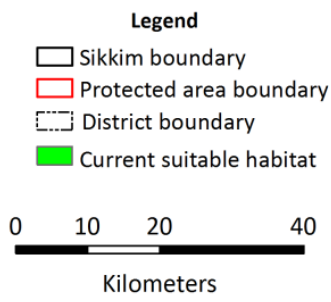

Figure 4. Predicted current potential habitat of P. pseudogensing overlaid on existed protected areas (red color lines) networks of Sikkim Himalaya. (1: Khangchendzonga National Park; 2: Shingba Rhododendron Sanctuary; 3: Kyangnosla Alpine Sanctuary; 4: Pangolakha Wildlife Sanctuary; 5: Fambunglho Wildlife Sanctuary; 6: Maenam Wildlife Sanctuary; 7: Barsey Rhododendron Sanctuary; 8: Kitam Bird Sanctuary)

Acknowledgments. The facilities provided by the Director, G.B. Pant National Institute of Himalayan Environment and Sustainable Development, Uttarakhand are gratefully acknowledged. This research did not receive any specific grant from funding agencies in the public, commercial, or not-for-profit sectors. The authors are also thankful to the Scientist In-charge, Botanical Survey of India, Sikkim Himalayan Circle, for providing information and providing access to the herbarium specimens.

\section{REFERENCES}

[1] Adhikari, D., Barik, S. K., Upadhaya, K. (2012): Habitat distribution modelling for reintroduction of Ilex khasiana Purk., a critically endangered tree species of northeastern India. - Ecological Engineering 40: 37-43.

[2] Alamgir, M., Mukul, S. A., Turton, S. M. (2015): Modelling spatial distribution of critically endangered Asian elephant and Hoolock gibbon in Bangladesh forest ecosystems under a changing climate. - Applied Geography 60: 10-19.

[3] Alarcón, D., Cavieres, L. A. (2015): In the right place at the right time: habitat representation in protected areas of South American Nothofagus-dominated plants after a dispersal constrained climate change scenario. - PLoS One 10: e0119952.

[4] Al-Qaddi, N., Vessella, F., Stephan, J., Al-Eisawi, D., Schirone, B. (2016): Current and future suitability areas of kermes oak (Quercus coccifera L.) in the Levant under climate change. - Regional Environmental Change 17: 143-156.

[5] Araujo, M. B., New, M. (2007): Ensemble forecasting of species distribution. - Trends in Ecology and Evolution 22: 42-47.

[6] Araujo, M. B., Pearson, R. G., Thuiller, W., Erhard, M. (2005): Validation of speciesclimate impact models under climate change. - Global Change Biology 11: 1504-1513. 
[7] Barber, Q. E. C. (2015): Assessing the vulnerability of rare plants using climate change velocity, habitat connectivity and dispersal ability. - Ph.D Thesis, University of Alberta.

[8] Buisson, L., Thuiller, W., Casajus, N., Lek, S., Grenouillet, G. (2010): Uncertainty in ensemble forecasting of species distribution. - Global Change Biology 16: 1145-1157.

[9] Burgess, N., Küper, W., Mutke, J., Brown, J., Westaway, S., Turpie, S., Meshack, C., Taplin, J., McClean, C., Lovett, J. C. (2005): Major gaps in the distribution of protected areas for threatened and narrow range Afrotropical plants. - Biodiversity and Conservation 14: 1877-1894.

[10] Champion, H. G., Seth, S. K. (1968): A Revised Survey of the Forest Types of India. Government of India, New Delhi.

[11] Chitale, V. S., Behera, M. D. (2012): Can the distribution of sal (Shorea robusta Gaertn. f.) shift in the northeastern direction in India due to changing climate? - Current Science 102: 1126-1135.

[12] Clarke, C. B. (1879): Aralia L. - In: Hooker, J. D. (ed.) Flora of British India. Vol II. Reeve and Co., London, pp 721-722.

[13] Clarke, L. E., Edmonds, J. A., Jacoby, H. D., Pitcher, H., Reilly, J. M., Richels, R. (2007): Scenarios of Greenhouse Gas Emissions and Atmospheric Concentrations. Subreport 2.1a of Synthesis and Assessment Product 2.1. - Climate Change Science Program and the Subcommittee on Global Change Research, Washington, DC.

[14] Corlett, R. T., Lafrankie, Jr. J. V. (1998): Potential impacts of climate change on tropical Asian forests through an influence on phenology. - Climate Change 39(2): 439-453.

[15] Cuyckens, G. A. E., Christie, D. A., Domic, A. I., Malizia, L. R., Renison, D. (2016): Climate change and the distribution and conservation of the world's highest elevation woodland in the South American Altiplano. - Global and Planetary Change 137: 79-87.

[16] Davis, M. B., Shaw, R. G. (2001): Range shifts and adaptive responses to Quaternary climate change. - Science 292(5517): 673-679.

[17] de Siqueira, M. F., Durigan, G., de Marco Júnior, P., Peterson, A. T. (2009): Something from nothing: using landscape similarity and ecological niche modeling to find rare plant species. - Journal for Nature Conservation 17(1): 25-32.

[18] Deb, J. C., Rahman, H. T., Roy, A. (2016): Freshwater swamp forest trees of Bangladesh face extinction risk from climate change. - Wetlands 36(2): 323-334.

[19] Diaz, H. F., Bradley, R. S. (1997): Temperature variations during the last centaury at high altitude elevation sites. - Climate Change 36: 253-279.

[20] Dotchamou, F. T., Atindogbe, G., Sode, A. I., Fonton, H. N. (2016): Density and spatial distribution of Parkia biglobosa pattern in Benin under climate change. - Journal of Agriculture and Environment for International Development 110(1): 173-194.

[21] Dowling, C. R. (2015): Using Maxent modeling to predict habitat of mountain Pine Beetle in response to climate change. - Ph.D. Thesis, University of Southern California.

[22] Elith, J., Graham, C. H., Anderson, R. P., Dudik, M., Ferrier, S., Guisan, A., Hijmans, R. J., Huettmann, F., Leathwick, J. R., Lehmann, A., Li, J., Lohmann, L. G., Loiselle, B. A., Manion, G., Moritz, C., Nakamura, M., Nakazawa, Y., Overton, J. M., Peterson, A. T., Phillips, S. J., Richardson, K., Scachetti-Pereira, R., Schapire, R. E., Soberon, J., Williams, S., Wisz, M. S., Zimmermann, N. E. (2006): Novel methods improve prediction of species distribution from occurrence data. - Ecography 29: 129-151.

[23] Elith, J., Phillips, S., Hastie, T., Dudik, M., Chee, Y. E., Yates, C. J. (2011): A statistical explanation of Maxent for ecologists. - Diversity and Distributions 17: 43-47.

[24] Fawcett, T. (2006): An introduction to ROC analysis. - Pattern Recognition Letters 27: 861-874.

[25] Fielding, A. H., Bell, J. F. L. (1997): A review of methods for the assessment of prediction errors in conservation presence/absence models. - Environmental Conservation 24(1): 38-49.

[26] Forrest, J. L., Wikramanayake, E., Shrestha, R., Areendran, G., Gyeltshen, K., Maheshwari, A., Mazumdar, S., Naidoo, R., Thapa, G. J., Thapa, K. (2012): Conservation 
and climate change: assessing the vulnerability of snow leopard habitat to treeline shift in the Himalaya. - Biological Conservation 150: 129-135.

[27] Franklin, J., Swanson, F., Harmon, M., Perry, D., Spies, T., Dale, V., McKee, A., Ferrell, W., Means, J., Gregory, S., Lattin, J., Schowalter, T., Walter, D. (1992): Effects of Global Climatic Change on Forests in Northwestern North America. - In: Peters, R. L., Lovejoy, T. E. (eds.) Global Warming and Biological Diversity. Yale University Press, New Haven, CT, pp. 244-257.

[28] Ghose, P. S., Sharma, B., Chakraborty, R., Legshey, K. (2011): Status of Red Panda in Sikkim: A Case Study in East Sikkim. - In: Arrawatia, M. L., Tambe, S. (eds.) Biodiversity of Sikkim - Exploring and Conserving a Global Hotspot. Information and Public Relations Department, Government of Sikkim, Gangtok, India, pp. 363-378.

[29] Grabherr, G., Gottfried, M., Pauli, H. (1994): Climate effects on mountain plants. Nature 369: 448.

[30] Gratani, L. (2014): Plant phenotypic plasticity in response to environmental factors. Advances in Botany. http://dx.doi.org/10.1155/2014/208747.

[31] Guisan A., Thuiller, W. (2005): Predicting species distribution: offering more than simple habitat models. - Ecology Letters 8: 993-1009.

[32] Guisan, A., Tingley, R., Baumgartner, J. B., Naujokaitis-Lewis, I., Sutcliffe, P. R., Tulloch, A. I. T., Regan, T. J., Brotons, L., McDonald-Madden, E., Mantyka-Pringle, C., Martin, T. G., Rhodes, J. R., Maggini, R., Setterfield, S. A., Elith, J., Schwartz, M. W., Wintle, B. A., Broennimann, O., Austin, M., Ferrier, S., Kearney, M. R., Possingham, H. P., Buckley, Y. M. (2013): Predicting species distributions for conservation decisions. Ecology Letters 16: 1424-1435.

[33] Hansen, A. J., Phillips, L. B. (2015): Which tree species and biome types are most vulnerable to climate change in the US Northern Rocky Mountains? - Forest Ecology and Management 338: 68-83.

[34] Hijmans, R. J., Cameron, S. E., Parra, J. L., Jones, P. G., Jarvis, A. (2005): Very high resolution interpolated climate surfaces for global land areas. - International Journal of Climatology 25: 1965-1978.

[35] Innes, J. L. (1991): High-altitude and high latitude tree growth in relation to past, present and future global climate change. - The Holocene 1: 168-173.

[36] IPCC (2014): Summary for Policymakers. In: Field, C. B., Barros, V. R., Dokken, D. J., Mach, K. J., Mastrandrea, M. D., Bilir, T. E., Chatterjee, M., Ebi, K. L., Estrada, Y. O., Genova, R. C., Girma, B., Kissel, E. S., Levy, A. N., MacCracken, S., Mastrandrea, P. R., White, L. L. (eds.) Climate Change 2014: Impacts, Adaptation, and Vulnerability. Part A: Global and Sectoral Aspects. Contribution of Working Group II to the Fifth Assessment Report of the Intergovernmental Panel on Climate Change. - Cambridge University Press, Cambridge, UK and New York, NY, pp. 1-32.

[37] Irfan-Ullah, M., Amartnath, G., Murthy, M. S. R. and Peterson, A. T. (2007): Mapping the geographic distribution of Agalia bourdillonii Gamble (Meliaceae), an endemic and threatened plant, using ecological niche modeling. - Biodiversity and Conservation 16: 1917-1925.

[38] Kang, W., Minor, E. S., Lee, D., Park, C. R. (2016): Predicting impacts of climate change on habitat connectivity of Kalopanax septemlobus in South Korea. - Acta Oecologica 71: 31-38.

[39] Khanum, R., Mumtaz, A. S., Kumar, S. (2013): Predicting impacts of climate change on medicinal asclepiads of Pakistan using Maxent modeling. - Acta Oecologica 49: 23-31.

[40] Koo, K. A., Kong, W. S., Nibbelink, N. P., Hopkinson, C. S., Lee, J. H. (2015): Potential effects of climate change on the distribution of cold-tolerant evergreen broadleaved woody plants in the Korean peninsula. - PLoS One 10(8): p.e0134043.

[41] Kumar, D. (2013): Distribution and mapping of selected tree species in different forest types of lower Assam region of India. - Ph.D. Thesis, North-Eastern Hill University, Shillong, India. 
[42] Kumar, P. (2012): Assessment of impact of climate change on Rhododendrons in Sikkim Himalayas using Maxent modelling: limitations and challenges. - Biodiversity and Conservation 21: 1251-1266.

[43] Li, R., Xu, M., Wong, M. H. G., Qiu, S., Li, X., Ehrenfeld, D., Li, D. (2015): Climate change threatens giant panda protection in the 21st century. - Biological Conservation 182: 93-101.

[44] Loiselle, B. A., Jorgensen, P. M., Consiglio, T., Jimenez, I., Blake, J. G., Lohmann, L. G., Montiel, O. M. (2008): Predicting species distributions from herbarium collections: does climate bias in collection sampling influence model outcomes? - Journal of Biogeography 35: 105-116.

[45] Maclean, I., Hopkins, J. J., Bennie, J., Lawson, C. R., Wilson, R. J. (2015): Microclimates buffer the responses of plant communities to climate change. - Global Ecology and Biogeography 24(11): 1340-1350.

[46] Manish, K., Telwala, Y., Nautiyal, D. C., Pandit, M. K. (2016): Modelling the impacts of future climate change on plant communities in the Himalaya: a case study from Eastern Himalaya, India. - Modeling Earth Systems and Environment 2: 92. DOI: 10.1007/s40808-016-0163-1.

[47] Marini, M. A., Barbet-Massin, M., Martinez, J., Prestesc, N. P., Jiguet, F. (2010): Applying ecological niche modelling to plan conservation actions for the Red-spectacled Amazon (Amazona pretrei). - Biological Conservation 143(1): 102-112.

[48] Menon, S., Soberon, J., Li, X. G., Peterson, A. T. (2010): Preliminary global assessment of terrestrial biodiversity consequences of sea-level rise mediated by climate change. Biodiversity and Conservation 19: 1599-1609.

[49] Midgley, G. F., Hughes, G. O., Thuiller, W., Rebelo, A. G. (2006): Migration rate limitations on climate change induced range shifts in Cape Proteaceae. - Diversity and Distributions 12: 555-562.

[50] Mohandass, D., Zhao, J. L., Xia, Y. M., Campbell, M. J., Li, Q. J. (2015): Increasing temperature causes flowering onset time changes of alpine ginger Roscoea in the Central Himalayas. - Journal of Asia-Pacific Biodiversity 8(3): 191-198.

[51] Moilanen, A., Anderson, B. J., Arponen, A., Pouzols, F. M., Thomas, C. D. (2013): Edge artefacts and lost performance in national versus continental conservation priority areas. Diversity and Distributions 19: 171-183.

[52] Moiseev, P. A., Shiyatov, S. G. (2003): The Use of Old Landscape Photographs for Studying Vegetation Dynamics at the Tree Line Ecotone in the Ural Highlands, Russia. In: Nagy, L. (ed.) Alpine Biodiversity in Europe. Springer-Verlag, Berlin, pp. 423-436.

[53] Monahan, W. B., Cook, T., Melton, F., Connor, J., Bobowski, B. (2013): Forecasting distributional responses of limber pine to climate change at management-relevant scales in Rocky Mountain National Park. - PLoS One 8(12): p.e83163.

[54] Moritz, C., Agudo, R. (2013): The future of species under climate change: resilience or decline? - Science 341(6145): 504-508.

[55] Nayar, M. P., Sastry, A. R. K. (1990): Red Data Book of Indian Plants. Vol. 3. Botanical Survey of India, Kolkatta.

[56] Pandit, M. K., Babu, C. R. (1998): Biology and conservation of Coptis teeta Wall: an endemic and endangered medicinal herb of Eastern Himalaya. - Environmental Conservation 25(3): 262-272.

[57] Pandit, M. K., Sodhi, N. S., Koh, L. P., Bhaskar, A., Brook, B. W. (2007): Unreported yet massive deforestation driving loss of endemic biodiversity in Indian Himalaya. Biodiversity and Conservation 16: 153-163.

[58] Pauli, H., Gottfried, M., Grabherr, G. (1996): Effects of climate change on mountain ecosystems: upward shifting of mountain plants. - World Research Review 8: 382-390.

[59] Pearson, R. G., Dawson, T. P. (2003): Predicting the impacts of climate change on the distribution of species: Are bioclimate envelope models useful? - Global Ecology and Biogeography 12: 361-371. 
[60] Pearson, R. G., Dawson, T. P. (2005): Long-distance plant dispersal and habitat fragmentation: identifying conservation targets for spatial landscape planning under climate change. - Biological Conservation 123: 389-401.

[61] Pearson, R. G., Dawson, T. P., Liu, C. (2004): Modelling species distributions in Britain: a hierarchical integration of climate and land-cover data. - Ecography 27: 285-298.

[62] Perez-Garcia, N., Font, X., Ferre, A., Carreras, J. (2013): Drastic reduction in the potential habitats for alpine and subalpine vegetation in the Pyrenees due to twenty-firstcentury climate change. - Regional Environmental Change 13(6): 1157-1169.

[63] Phillips, S. J., Dudik, M. (2008): Modeling of species distributions with Maxent: new extensions and a comprehensive evaluation. - Ecography 31: 161-175.

[64] Phillips, S. J., Anderson, R. P., Schapire, R. E. (2006): Maximum entropy modeling of species geographic distributions. - Ecological Modelling 190: 231-259.

[65] Priti, H., Aravind, N. A., Shaanker, R. U., Ravikanth, G. (2016): Modeling impacts of future climate on the distribution of Myristicaceae species in the Western Ghats, India. Ecological Engineering 89: 14-23.

[66] Riahi, K., Grübler, A., Nakicenovic, N. (2007): Scenarios of long-term socio-economic and environmental development under climate stabilization. - Technological Forecasting and Social Change 74(7): 887-935.

[67] Riahi, K., Krey, V., Rao, S., Chirkov, V., Fischer, G., Kolp, P., Kindermann, G., Nakicenovic, N., Rafai, P. (2011): RCP-8.5: exploring the consequence of high emission trajectories. - Climatic Change 109: 33. DOI: 10.1007/s10584-011-0149-y.

[68] Rodgers, W. A., Panwar, H. S., Mathur, V. B. (2000): Wildlife Protected Area Network in India: A Review, Executive Summary. - Wildlife Institute of India, Dehradun.

[69] Royle, J. A., Chandler, R. B., Yackulic, C., Nichols, J. D. (2012): Likelihood analysis of species occurrence probability from presence-only data for modelling species distributions: Likelihood analysis of presence-only data. - Methods in Ecology and Evolution 3(3): 545-554.

[70] Saltré, F., Duputié, A., Gaucherel, C., Chuine, I. (2015): How climate, migration ability and habitat fragmentation affect the projected future distribution of European beech. Global Change Biology 21(2): 897-910.

[71] Sanchez, A. C., Osborne, P. E., Haq, N. (2011): Climate change and the African baobab (Adansonia digitata L.): the need for better conservation strategies. - African Journal of Ecology 49: 234-245.

[72] Saran, S., Joshi, R., Sharma, S., Padalia, H., Dadhwal, V. K. (2010): Geospatial modeling of Brown oak (Quercus semecarpifolia) habitats in the Kumaun Himalaya under climate change scenario. - Journal of the Indian Society of Remote Sensing 38: 535-547.

[73] Sathyakumar, S., Poudyal, K., Bhattacharya, T., Bashir, T. (2011a): Galliformes of Khangchendzonga Biosphere Reserve, Sikkim, Inidia. - In: Arrawatia, M. L., Tambe, S. (eds.) Biodiversity of Sikkim-Exploring and Conserving a Global Hotspot. Information and Public Relations Department, Government of Sikkim, Gangtok, India.

[74] Sathyakumar, S., Bashir, T., Bhattacharya, T., Poudyal, K. (2011b): Assessing mammal distribution and abundance in intricate eastern Himalayan habitats of Khangchendzonga, Sikkim, India. - Mammalia 75: 257-268.

[75] Schröter, D., Cramer, W., Leemans, R., Prentice, I. C., Araújo, M. B., Arnell, N. W., Bondeau, A., Bugmann, H., Carter, T. R., Gracia, C. A., de la Vega-Leinert, A. C., Erhard, M., Ewert, F., Glendining, M., House, J. I., Kankaanpää, S., Klein, R. J., Lavorel, S., Lindner, M., Metzger, M. J., Meyer, J., Mitchell, T. D., Reginster, I., Rounsevell, M., Sabaté, S., Sitch, S., Smith, B., Smith, J., Smith, P., Sykes, M. T., Thonicke, K., Thuiller, W., Tuck, G., Zaehle, S., Zierl, B. (2005): Ecosystem service supply and vulnerability to global change in Europe. - Science 310(5752): 1333-1337.

[76] Settele, J., Bishop, J., Potts, S. G. (2016): Climate change impacts on pollination. Nature Plants 2: 16092. DOI: 10.1038/nplants.2016.92. 
[77] Sharma, S. K., Pandit, M. K. 2011. A morphometric analysis and taxonomic study of Panax bipinnatifidus Seem. (Araliaceae) species complex from Sikkim Himalaya, India. - Plant Systematics and Evolution 297: 87-98.

[78] Shrestha, U. B., Bawa, K. S. (2014): Impact of climate change on potential distribution of Chinese caterpillar fungus (Ophiocordyceps sinensis) in Nepal Himalaya. - PLoS One 9(9): e106405. DOI: 10.1371/journal.pone.0106405.

[79] Shrestha, U. B., Gautam, S., Bawa, K. S. (2012): Widespread climate change in the Himalayas and associated changes in local ecosystems. - PLoS One 7(5): e36741. DOI: 10.1371/journal.pone.0036741.

[80] Singh, K. P., Kushwaha, C. P. (2016): Deciduousness in tropical trees and its potential as indicator of climate change: A review. - Ecological Indicators 69: 699-706.

[81] Singh, S. P., Singh, V., Skutsch, M. (2010): Rapid warming in the Himalayas: ecosystem responses and development options. - Climate and Development 2: 1-13.

[82] Smith, S. J., Wigley, T. M. L. (2006): Multi-gas forcing stabilization with minicam. The Energy Journal 3: 373-392.

[83] Sohel, S. I., Akhter, S., Ullah, H., Haque, E., Rana, P. (2016): Predicting impacts of climate change on forest tree species of Bangladesh: evidence from threatened Dysoxylum binectariferum (Roxb.) Hook. f. ex Bedd. (Meliaceae). - iForest 10: 154. DOI: 10.3832/ifor1608-009.

[84] Stockwell, D. R. B., Peterson, A. T. (2002): Effects of sample size on accuracy of species distribution models. - Ecological Modelling 148: 1-13.

[85] Svenning, J. C., Harlev, D., Sørensen, M. M., Balslev, H. (2009): Topographic and spatial controls of palm species distributions in a montane rain forest, southern Ecuador. Biodiversity and Conservation 18: 219-228.

[86] Swets, J. (1988): Measuring the accuracy of diagnostic systems. - Science 240: 12851293.

[87] Tear, T. H., Kareiva, P., Angermeier, P. L., Comer, P., Czech, B., Kautz, R., Landon, L., Mehlman, D., Murphy, K., Ruckelshaus, M., Scott, J. M., Wilhere, G. (2005): How much is enough? The recurrent problem of setting measurable objectives in conservation. BioScience 55: 835.

[88] Telwala, Y., Brook, B. W., Manish, K., Pandit, M. K. (2013): Climate-induced elevational range shifts and increase in plant species richness in a Himalayan biodiversity epicentre. - PLoS One 8(2): e57103.

[89] Thomas, C. D., Cameron, A., Green, R. E., Bakkenes, M., Beaumont, L. J., Collingham, Y. C., Erasmus, B. F., De Siqueira, M. F., Grainger, A., Hannah, L., Hughes, L. (2004): Extinction risk from climate change. - Nature 427(6970): 145-148.

[90] Thuiller, W., Lavorel, S., Araújo, M. B., Sykes, M., Prentice, I. C. (2005): Climate change threats to plant diversity in Europe. - Proceedings of National Academy of Sciences 102: 8245-8250.

[91] Thuiller, W., Broennimann, O., Hughes, G. O., Alkemade, J. R. M., Midgley, G. F., Corsi, F. (2006): Vulnerability of African mammals to anthropogenic climate change under conservative land transformation assumptions. - Global Change Biology 12: 424440.

[92] Trisurat, Y., Rajendra, P., Shrestha, B., Kjelgren, R. 2011. Plant species vulnerability to climate change in peninsular Thailand. - Applied Geography 31: 1106-1114.

[93] Urbina-Cardona, J. N., Flores-Villela, O. (2010): Ecological niche modeling and prioritization of conservation area networks for Mexican herpetofauna. - Conservation Biology 24(4): 1031-1041.

[94] Warren, D. L., Glor, R. E., Turelli, M. (2010): ENMTools: a toolbox for comparative studies of environmental niche models. - Ecography 33: 607-611.

[95] Wise, M., Calvin, K., Thomson, A., Clarke, L., Bond-Lamberty, B., Sands, R., Smith, S. J., Janetos, A., Edmonds, J. (2009): Implications of limiting $\mathrm{CO}_{2}$ concentrations for land use and energy. - Science 324: 1183-1186. 
[96] Yi, Y. J., Cheng, X., Yang, Z. F., Zhang, S. H. (2016): Maxent modeling for predicting the potential distribution of endangered medicinal plant ( $H$. riparia Lour) in Yunnan, China. - Ecological Engineering 92: 260-269.

[97] York, E. M., Butler, C. J., Lord, W. D. (2016): Global decline in suitable habitat for Angiostrongylus (=Parastrongylus) cantonensis: the role of climate change. - PLoS One 9(8): e103831. DOI: 10.1371/journal.pone.0103831.

[98] Zhang, Y., Wang, Y., Zhang, M., Ma, K. (2014): Climate change threats to protected plants of China: an evaluation based on species distribution modeling. - Chinese Science Bulletin 59(34): 4652-4659.

\section{APPENDIX}

\section{Uncertainty among model predictions}

It should be noted that only three global circulation models (GCMs; MRI-CGCM3, CSIRO-MK3.6 and HadGEM2-CC) under two future climate scenarios (RCP 4.5 and 8.5) were used in this study (Fig. Al).

Figure A1. Differences in future potential predictions, among three different Global Circulation Models (GCMS) viz.; CGCM3, CSIRO-MK3 and HadGEM2-CC for Panax pseudoginseng. Where cyan color shows unsuitable prediction, yellow color shows predicted suitable habitat area by at least one of the GCMs, green color shows predicted suitable habitat area by two GCMs, and red shows predicted suitable habitat area by all three GCMs

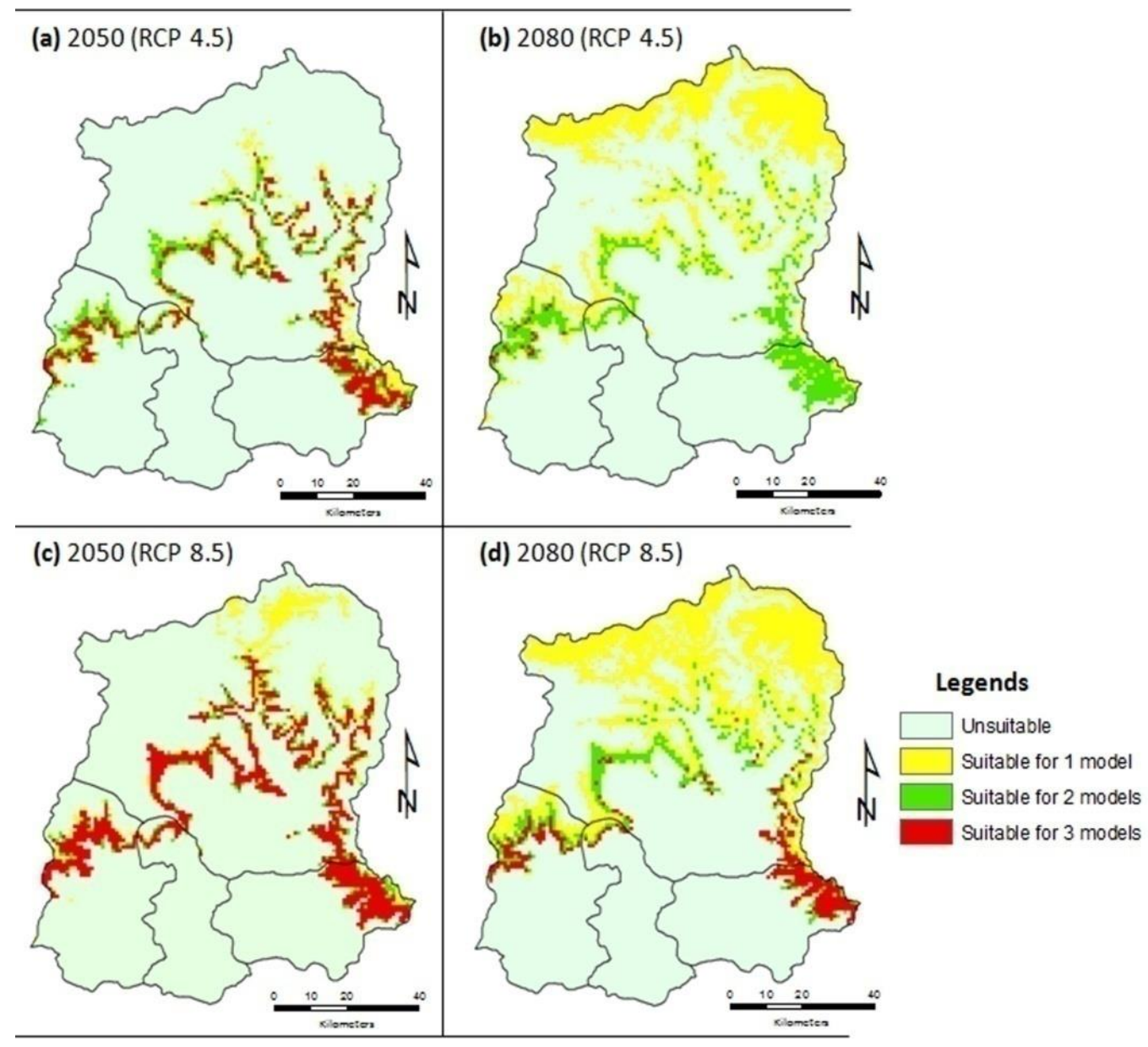


Other scenarios and GCMs could give different results. Buisson et al. (2010) accounted that the Maxent or other modeling algorithms used could yield large variation in projections, followed by GCM, whose contribution increased over time. In order to report for certain future uncertainty Buisson et al. (2010) recommended using several GCMs and scenarios. Model projections also depend on the year. The years 2050 and 2070 are commonly used in studies dealing with the impacts of climate change on biodiversity (Thuiller et al., 2006; Khanum et al., 2013; Dowling, 2015; Hansen and Phillips, 2015; Koo et al., 2015; Al-Qaddi et al., 2016; Deb et al., 2016; Sohel et al., 2016). As expected, projections for 2070 displayed more negative impacts than projections for 2050(described by Thuiller et al., 2006; York et al. 2014) in RCP 8.5 scenario of climate change. However, in RCP 4.5 scenario projections for 2050 and 2070 displayed less likely to negative impacts.

A pertinent question which arises while studying the potential future distribution of a species is the validity and/or accuracy of the GCM and scenarios commonly used for this purpose, as different GCM from different climatic research centers show different results. However, to date, this is the best data available, and it is still commonly used to study the potential effect of climate change on species' distributions (Buisson et al., 2010; Marini et al., 2010; Khanum et al., 2013; Dowling, 2015; Hansen and Phillips 2015; Koo et al., 2015; Al-Qaddi et al., 2016; Deb et al., 2016; Sohel et al., 2016; Kang et al., 2016). The precautionary principle suggests that the uncertainty about predicted changes in climate does not justify lack of action. It is better to use the data which is available and carry out the studies required to make recommendations for conservation.

Table A1. Pairwise correlation matrix (Pearson's correlation coefficients, $r$ ) between bioclimatic variables. Variables showing $(r) \geq 0.9$ were excluded from the analysis, and only six variables included in this study (i.e., Bio3, Bio7, Bio10, Bio11, Bio15 and Bio18)

\begin{tabular}{|c|c|c|c|c|c|c|c|c|c|c|c|c|c|c|c|c|c|c|}
\hline Variables & Bio1 & Bio2 & Bio3 & Bio4 & Bio5 & Bio6 & Bio7 & Bio8 & \begin{tabular}{|l|l} 
Bio9 \\
\end{tabular} & Bio10 & Bio11 & Bio12 & Bio13 & Bio14 & 4 Bio15 & Bio16 & Bio17 & Bio18 \\
\hline Bio2 & -0.518 & & & & & & & & & & & & & & & & & \\
\hline Bio3 & 0.319 & 0.208 & & & & & & & & & & & & & & & & \\
\hline Bio4 & -0.592 & 0.975 & 0.008 & & & & & & & & & & & & & & & \\
\hline Bio5 & 0.850 & 0.008 & 0.476 & -0.088 & & & & & & & & & & & & & & \\
\hline Bio6 & 0.925 & -0.794 & 0.201 & -0.853 & 0.591 & & & & & & & & & & & & & \\
\hline Bio7 & -0.586 & 0.987 & 0.063 & 0.997 & -0.075 & -0.849 & & & & & & & & & & & & \\
\hline Bio8 & 0.957 & -0.249 & 0.401 & -0.334 & 0.966 & 0.776 & -0.326 & & & & & & & & & & & \\
\hline Bio9 & 0.977 & -0.678 & 0.269 & -0.748 & 0.724 & 0.984 & -0.742 & 0.875 & & & & & & & & & & \\
\hline Bio10 & 0.957 & -0.249 & 0.401 & $\mid-0.334$ & 0.966 & 0.776 & -0.326 & 1.000 & 0.875 & & & & & & & & & \\
\hline Bio11 & 0.980 & -0.670 & 0.269 & -0.740 & 0.732 & 0.982 & -0.734 & 0.881 & 1.000 & 0.881 & & & & & & & & \\
\hline Bio12 & 0.742 & -0.955 & -0.022 & -0.968 & 0.280 & 0.936 & $|-0.974|$ & 0.515 & 0.862 & 0.515 & 0.856 & & & & & & & \\
\hline Bio13 & 0.646 & -0.970 & -0.060 & -0.977 & 0.160 & 0.879 & $\mid-0.982$ & 0.401 & 0.785 & 0.401 & 0.778 & 0.986 & & & & & & \\
\hline Bio14 & 0.741 & -0.887 & 0.200 & -0.954 & 0.313 & 0.928 & -0.942 & 0.528 & 0.860 & 0.528 & 0.852 & 0.952 & 0.934 & & & & & \\
\hline Bio15 & -0.200 & -0.573 & -0.104 & -0.575 & -0.588 & 0.147 & $-0.567 \mid$ & -0.434 & -0.013 & -0.434 & -0.026 & 0.413 & 0.551 & 0.424 & & & & \\
\hline Bio16 & 0.657 & -0.974 & -0.046 & -0.984 & 0.169 & 0.890 & -0.989 & 0.412 & 0.796 & 0.412 & 0.789 & 0.990 & 0.998 & 0.946 & 0.532 & & & \\
\hline Bio17 & 0.814 & -0.897 & 0.127 & -0.946 & 0.395 & 0.971 & -0.941 & 0.613 & 0.917 & 0.613 & 0.890 & 0.979 & 0.943 & 0.976 & 0.316 & 0.955 & & \\
\hline Bio18 & 0.657 & -0.974 & -0.046 & -0.984 & 0.169 & 0.890 & -0.989 & 0.412 & 0.796 & 0.412 & 0.789 & 0.990 & 0.998 & 0.946 & 0.532 & 1.000 & 0.955 & \\
\hline Bio19 & 0.870 & -0.840 & 0.181 & -0.900 & 0.494 & 0.984 & -0.893 & 0.696 & 0.951 & 0.696 & 0.856 & 0.951 & 0.894 & 0.953 & 0.194 & 0.909 & 0.990 & 0.864 \\
\hline
\end{tabular}

